\title{
RESENTMENT: NEUROSCIENCES APPLIED TO PSYCHOANALYSIS, A TRANSDISCIPLINARY THEORETICAL ESSAY
}

\section{THEORETICAL TEST}

MELLO, Paulo de ${ }^{1}$, BERTINI, Edna², FREIRE, Lázaro Luiz Trindade ${ }^{3}, J^{2}$ ACINTO, Débora Damasceno ${ }^{4}$, BORGES, Tássia Monteiro ${ }^{5}$

MELLO, Paulo de. Et al. Resentment: neurosciences applied to psychoanalysis, a transdisciplinary theoretical essay. Revista Científica Multidisciplinar Núcleo do Conhecimento. Year 06, Ed. 11, Vol. 06, pp. 133-146. November 2021. ISSN: 24480959, Access link: https://www.nucleodoconhecimento.com.br/psychology/neurosciences-applied, DOI: 10.32749/nucleodoconhecimento.com.br/psychology/neurosciences-applied

\section{ABSTRACT}

With this article we aim to present a transdisciplinary conception of the relationship between neuroscience and psychoanalysis, especially Kleinian, in the field of epiphenomenos linked to resentment, its meaning and fundamental mechanisms of a psychoanalytic and biological nature. The article is the result of a theoreticalqualitative study based on the experience of the authors, some with more than 30

\footnotetext{
${ }^{1} \mathrm{PhD}$ student in Clinical Psychology from the University of Business and Social Sciences (UCES/Buenos Aires/Argentina); Master in Health Psychology from the Methodist University of São Paulo (UMESP/SP/Brazil); Specialist in Behavioral Medicine from the Federal University of São Paulo (UNIFESP/SP/Brazil); Clinical Neurologist from the Federal University of São Paulo (UNIFESP/SP/Brazil); Medical from the University of Taubaté (UNITAU/SP/Brazil).

${ }^{2} \mathrm{PhD}$ in Pharmacology from the Institute of Biomedical Sciences (USP/SP/Brazil). Master in Pharmacology from the Institute of Biomedical Sciences (USP/SP/Brazil). Specialist in Behavioral Medicine (UNIFESP/SP/Brazil). Psychoanalyst trained in Transpersonal Psychoanalysis (IBT). Psychoanalyst trained in Reich analysis (IBAR). ${ }^{3}$ Psychoanalyst trained in Transpersonal Psychoanalysis (IBT). Graduated in Electrical Engineering from the Pontifícia Universidade Católica (PUC/MG/Brazil). Graduated in Philosophy (UNIFAI/PUC/SP/Brazil).

${ }^{4}$ Psychoanalyst graduated from the Faculty of Psychoanalysis and Human Sciences (EPCH/SP/Brazil). Specialist in Psychoanalytic Theory (Sorbonne/Paris/France). Graduated in Philosophy from the University of São Paulo (USP/SP/Brazil).

${ }^{5}$ Master's student in Clinical Psychology at the Pontifícia Universidade Católica de São Paulo (PUC/SP/Brazil). Psychoanalyst from the FACEI School (SP/Brazil). Graduated in Letters from the University of São Paulo (FFLCH/USP/SP/Brazil).
}

RC: 102908

Available in: https://www.nucleodoconhecimento.com.br/psychology/neurosciencesapplied 
years of clinical experience in the area of mental health, psychoanalysis and neuroscience, added to a bibliographic review that consists mainly of books in the field of psychoanalysis, analysis and Freudian psychoanalysis, Kleinian and Jungian, a total of 21 books researched, as well as articles in the field of neuroscience. Researched in the PubMed, Medline and Scielo databases in the period between 2000 and 2020. Epistemological trimming involves elements such as objectual relationship, neurotransmitters, structures and neural circuits involved in the phenomenon of resentment. Texts that were outside the qualitative and transdisciplinary scope of the study of the text were excluded. We use the intuitiveinterpretative method whose conclusion reinforces the viability of the understanding of psychoanalytic phenomena such as psychic determinism and object relations via intersection with neurobiological mechanisms that are developed through mental operations (mentalization), and psychopharmacological intervention and neuromodulation by transcranian magnetic stimulation, thus expanding knowledge on the subject for the areas in question.

Keywords: resentment, neuropsychoanalysis, psychoanalysis, mentalization.

\section{INTRODUCTION}

Based on the desire to expand knowledge in the area of transdisciplinary research between neuroscience and psychoanalysis, we developed a theoretical-qualitative study supported by the clinical experience of the authors and review of texts, books and articles aiming to demonstrate the feasibility of developing transdisciplinary studies between apparently so different areas, not with the aim of validation, but to broaden the understanding of each area by looking for points of convergence between them (TURATO, 2005; HULLEY et al., 2008).

For this article we chose to study resentment, a common phenomenon, responsible for the emotional and physical suffering of many of those who seek care in medical, psychological and psychoanalytic offices. 
Based on this small introduction, we understand, as part of our worldview, that the self - our conscious idea of who we are or what we are (HOLLIS, 1998) - arises as a virtual element because it cannot be palpated, nor do we know what matter it is made of, meanwhile it appears at some point in the pre or neo natal period with the almost obsessive objective of seeking security, to stay alive and to preserve the species; something that arises in the evolutionary process, similar to the animal's claw, its teeth and speed. Seen in this way, the self can be a fundamental phenomenological representative of physical life and the physical body, having its natural origin in brain function as this same brain develops.

Seen in this way, the development of the self is realized as a resource of the physical body, just like a software managed by the brain. Its nature or the nature of its manifestation in the time/space universe is bioelectrical and biochemical and the quality and forms of expression can be modified, intensified or repressed by means of pharmacological neuromodulation and most likely by magnetic neuromodulation by means of transcranial magnetic stimulation (TMS).

Our review allows us to affirm that there are reasonably specific neural systems involved in the development and improvement of the self, object relationships and innate aggressiveness. These data corroborate with the Kleinian theory.

\section{ME}

As we said earlier, we understand that the self is basically the conscious idea of who we are or what we are (HOLLIS, 1998).

At the beginning we can explain that the meso limbic system (dopaminergic), and meso cortical, together, form a system that drives the individual to explore his relationship with the Other in the figure of someone outside him, a partial object at the beginning (to satisfy his needs), and then, a total object (to satisfy his desires).

For this reason, this system is fundamental for the development of the object relationship, of the catéxia and for the improvement of the functions said yoicas. So

RC: 102908

Available in: https://www.nucleodoconhecimento.com.br/psychology/neurosciencesapplied 
far we understand that object relations are fundamental to the structuring of the self; and for there to be object relations, there is a need for the brain to develop more than object representations, but also to be able to introject essential or primordial objects by going beyond representations.

The self, like the other structures of Freud's 2nd topic, develops, because over the years it is fed with a set of information that accumulates day by day from the internal and external universe to the individual.

The universe external to the individual is felt by him from exteroception (temperature, pain, touch, vision, hearing, palate and smell), proprioception (sensory perception coming from tendons, ligaments, joints and muscles) and interoception (the same for blood vessels and viscera).

It is through these senses that the brain is fed by an innumerable volume of information whose objective is to improve the adaptive capacity of the subject and his object relations. Through this process the self develops mechanisms or resources that visa its survival, are the said defenses of the self; resources directly dependent on the development and maturation of the prefrontal cortex, but not just this.

\section{MENTALIZATION AND RESENTMENT}

Mentalization or mentalization-based treatment (MBT) takes into account the ability to try to understand the phenomenological, relational, representative and biological mechanisms of events of a mental nature, such as: thoughts, beliefs, representations, feelings, desires and desires (BATEMAN; FONAGY, 2016).

The term Mentalization emerged with Peter Fonagy and other authors in an attempt to better understand and seek a model psychotherapeutic approach for patients with borderline personality disorder.

According to Cryan and Quiroga (2013), the secure affective bond, especially in the first years of life, is fundamental for the good development of mental functioning 
patterns that result in a more adapted subject and with more functional social relationships and why not say, learning. In this way, we understand that resentment can be the result of the development of a routine of dysfunctional mental operations in environments that do not offer the child safe affective conditions.

Mentalization requires careful and contextualized analysis and its use and development in the field of psychotherapy has grown in recent years, especially for the treatment of post-traumatic stress disorder, personality disorders, drug addiction and eating disorders. It is necessary, in mentalization, as a therapeutic approach, to carefully evaluate the behavioral routines, object relationships and experiences to which the individual was exposed and in the past was exposed. It recruits complex cognitive processes and their mechanisms occur mainly on a preconscious level (BATEMAN; FONAGY, 2016).

4 different dimensions were identified for a mentalization, namely: Automatic mentalization versus controlled mentalization; Mentalization in oneself versus mentalization in others; Mentalization with a view to internal versus external aspects; and Cognitive versus affective mentalization (LIEBERMAN, 2007).

So, considering this theoretical and practical model with respect to the psychotherapeutic approach Mentalization, we could say that the result of a set of routine and mental operations of automatic predominance, in itself, with a view to the internal and affective aspects, when in imbalance, can give rise to this complex phenomenon called resentment.

Therefore, we understand that psychoanalytic knowledge and other techniques, combined with an understanding of the mental patterns related to the resentful subject, can contribute greatly to the development and application of psychotherapeutic tools in their treatment. 


\section{MODULATING THE SELF IS MADE POSSIBLE BY PSYCHOPHARMACOLOGY AND TMS}

It is indisputable fact that the supply of antidepressants of diverse classes is able to modulate brain functions and provide remission of depressive symptoms from a complicated and intricate mechanism that involves receptors, reuptake of neurotransmitters, activation of DNA transcription at least in the medium term and finally neuroplasticity.

Studies showed that neuroplasticity is one of the mechanisms of action of antidepressants, especially neuroplasticity involves the ventral portion of the denteated gyration of hippocampal formation by increased neurotrophins, particularly BDNF. Antidepressants increase BDNF and therefore promote neuroplasticity (YAMADA et al., 2013). This is indisputable proof that psychotropic drugs promote structural changes in neural systems.

We know from more recent works that it is possible to reduce ruminative, depressive and self-deprecating cognitive processes by stimulating the dorsolateral region of the prefrontal cortex (CPFDL) or by inhibiting its contralateral homologous area using transcranial magnetic stimulation (TMS). If such neuromodulation is feasible, modifying features or at least manifesting them, something we might classify as ego, is also feasible.

Thus, if we can indeed modify its expression, it is because the ego is liable to be influenced by the chemistry of psychotropic drugs and by the application of magnetic fields with the potential to increase or reduce the activity of specific areas of the brain. 


\section{RESENTMENT; AGGRESSIVENESS OF INNATE NATURE AND BRAIN AVERSIVE SYSTEM}

So far, we understand that all these perceptual models - exteroception, proprioception and interoception - are external in nature to the innate mental process, even to the interoceptive ones. It is a fact that all this information participates in the construction of the mental universe, but perhaps Melanie Klein (1996) was right when she said that at birth we are endowed with innate mechanisms that mobilize us forward, through not only nutrition and sexuality, but also through aggressiveness.

What scientific evidence do we have on this claim, that aggressiveness is so innate in terms of the neuronal metaprograms responsible for nutrition and reproduction?

There is a set of neuronal structures and circuits in the brain described as the brain aversive system (SAC). This system is formed by the periaquedutal substance, periventricular nuclei of the hypothalamus and central nuclei of the amygdala. This cerebral aversive system is modulated by the prefrontal cortex and is activated when the subject feels physically or emotionally threatened. Alcohol, for example, inhibits the prefrontal cortex (CPF), which reduces inhibition of SAC by facilitating aggressive behaviors. Since selective serotonin reuptake inhibitor drugs raise serotonergic activity in this circuit which results, we can anticipate, in greater control over the SAC, in practice, greater social tolerance (BRANDÃO et al., 2003)

In an article published in the journal Nature Neuroscience, Stagkourakis et al. (2018), conducted a preclinical study with rodents using optogenetics. In this material, the mechanisms that regulate aggression among men in determining their social position were studied, targeting the ventral pre-mammillary hypothalamic nucleus (PMv), as a fundamental structure in the regulation of aggressive stimuli. According to the authors, PMv core stimulation triggers aggressive behaviors that are maintained for weeks after brief stimulation. For this phenomenon, the author used the term hysteresis.

RC: 102908

Available in: https://www.nucleodoconhecimento.com.br/psychology/neurosciencesapplied 
Hysteresis is the tendency that a system manifests itself by preserving its properties in the absence of the stimulus that produced them. This means that, after stimulating, the PMv nucleus continues to shoot electrical potentials for weeks whose phenomenological representative, in this case, is aggressiveness. Considering that the PMv nucleus is hypothalamic, we can infer that this subcortical system contains an innate behavioral metaprogram for the aggressiveness already present and functioning, perhaps, even before the neonatal period. This reasoning corroborates for a better transdisciplinary understanding of the claim, according to Kleinian theory, that aggressiveness is as innate as other reports of metaprograms to nutrition and sexuality.

Hrabovszky et al. (2005), identified three neuronal phenotypes in the hypothalamic structure that are involved in the induction of aggressiveness, these are: glutatergic neurons that co-express with thyreotropin-releasing hormone, glutatergic neurons without thyreotropin-releasing hormones, and energetic GABA neurons scattered among glutametergic cells.

These are, so far, the communicating and regulatory elements of aggressiveness present in the hypothalamus and if resentment were, in fact, an aggressive and lasting act against itself - death drive - perhaps these are the key neurotransmitters in the process of neural communication whose final phenomenon is what we call resentment.

\section{RESENTMENT: COMPLEX FUNCTIONAL MECHANISM THAT SEEKS THE SURVIVAL OF THE SELF AND IS USED OF PROJECTIVE IDENTIFICATION}

In the attempt to conceptualize resentment we will rely on the book "Resentimiento: clínica psicoanalítica", author Maria Rita Kehl (2004).

To resent, according to the author, means to attribute to another the responsibility for what makes us suffer, since this Other is imputed the guilt of the one whose 
expectation was not reciprocated. Thus, the resentful feels unable to engage as a subject of desire and even that resentment is not a psychoanalytic concept, it seems that "(...) it is a compromise solution between the field of narcissism and that of the Other." (KEHL, 2004, p.11). According to the author, "(...) the resentful is not someone incapable of forgetting or forgiving, it is one who does not want to forget or who wants not to forget, not to forgive, not to leave cheap the evil that victimized him". (KEHL, 2004, p.12).

According to Scheler (1958), psychological poisoning - resentment - is the result of the reorientation of aggressive impulses towards the self, thus generating the impossibility of removing from memory the attitude considered to be the nature of their resentment. Guilt is the feeling that the resentful seeks to attribute to the Object of his resentment; and, in Kleinian terms, this happens through projective identification (KLEIN, 1996). Thus, the resentful seeks to make the other suffer their suffering, the suffering of guilt, emptiness, abandonment, negligence and aggressiveness against themselves.

According to Rosenfeld (1971), the process of projective identification (IPry) refers to a process of cleavage of the more archaic self. Considering that the process of resentment involves, within other defensive mechanisms of the self, the IPry, we can say that the resentful, as a result of this incision, projects partial objects represented by love or hate objects into external objects (OExt).

If he were in the Schizoparanoid position, the resentful would perceive the OExt as a pursuer (ALMEIDA, 2003), but if he were in the Viscocardial position (MELLO et al., 2017), the aggressor will be perceived as the missing desired object, the one who abandons the resentful to his own fate, as if he were unable to sustain himself and survive in the absence of the OExt, as if it represented the mother or even the uterus that nourishes, or that should, in its unconscious conception, nourish it. It is an agglutinated object, which according to Bleger (1977), comprises a complex symbolic system where good and bad partial objects (OPC) mix and cannot be discriminated against (KLEIN, 1996). 
In this way, there is no clear delimitation between the self and the non-self, between the internal and the external; and for this reason, resentment is mobilized en bloc trying to drag with it the part that it considers as being its own, its aggressor, within the symbiotic process, this is why IPry is used as a primary resource.

A fundamental condition for the development of resentment is that the resentful person feels weakened by his aggressor, added to the refusal of the subject to leave the dependence instituted by his aggressor, the child dependence on someone who is supposed to protect him (KEHL, 2004) and offer him nurturance, continence.

Thus, in childhood, the Other, the aggressor of the resentful is represented by the figures who had effective power to protect, reward and punish the child (KEHL, 2004).

On a neo-Kleinian vision, the symbiotic and fusional relationship, inherent in the Viscocardial position, initially described in Spanish as Ghlischro-cárica by José Bleger (1977), would make explicit resentment as a desperate act of the self to remain fused to the referential Object, for whom, its demand for love, desire for protection and continence is projected and at the minimum partially frustrated (MELLO et al., 2017).

Staying fused, for the resentful is a goal of survival since he believes he cannot sustain himself and survive in the absence of the agglutinated object. When this system fails, diffusion arises and a deep feeling of fear is installed, what we call defusional anxiety, a feeling of imminent death and disorganization of thought especially in its form, manifested in the physical dimension such as shortness of breath, palpitation, chest pain, weakness or anthill by the body, result of the deconstruction of the agglutinated nucleus and weakening of the self.

In the field of neuroscience and mental health this picture not only resembles what psychiatry and neurology calls panic anxiety disorder, but in fact it is truly a panic syndrome, except in the situation where such symptoms manifest themselves as a result of persecutory anxiety, common to the schizopanoid position to the reverse of RC: 102908

Available in: https://www.nucleodoconhecimento.com.br/psychology/neurosciencesapplied 
manifesting as a result of a defusion anxiety, object of our study, common to the viscocardial position (MELLO et al., 2017).

Panic syndrome arises from alteration in the excitatory sensitivity of a network of circuits that surround structures such as the prefrontal cortex, cingulate gyrus, insula, thalamus, tonsils and projections of the tonsilloid nucleus for the brainstem, hypothalamus and septo-hippocampal system. The neurotransmitters most frequently involved in this modulation are noradrenaline and serotonin (MEZZASALMA et al., 2004).

Apparently the brain enters a state of emergency and then of urgency, activating nuclei, circuits and systems that generate an intense state of attention and then of disorientation in recurrence to noradernergic activation in the aforementioned areas. Perhaps the immediate nature of this dysfunction is the separation between objects, according to author Walter Trinca:

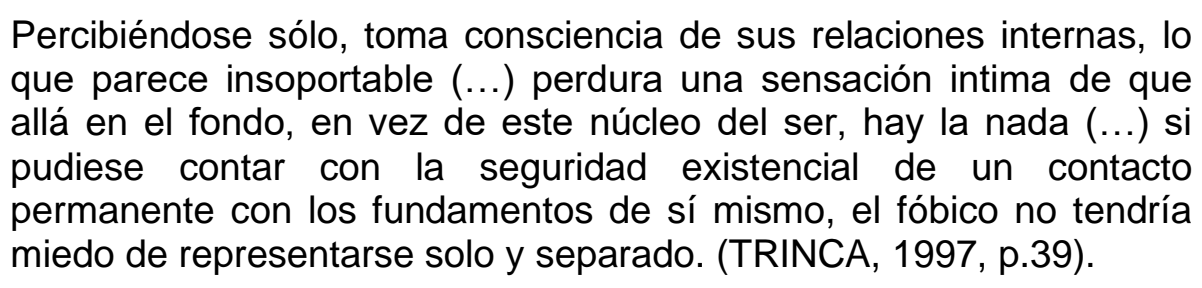

This is perhaps the immediate nature of the fear that arises when the psychological resources and mental operations used during the complex referred to as resentment do not work properly. In the meantime it is true that in addition to the said immediate causes, there are the mediate causes and causes of the trait.

We point out as immediate causes, those linked to the immediate triggering of fear, namely, the diffusion, the separation between objects, as referred to by Walter Trinca and José Bleger. The mediate causes - referred to as part of the psychic determinism of psychoanalysis - involve epigenetic mechanisms resulting from the exposure of the baby and the infant to the relationships with their referential objects, especially to the maternal figure, the family environment and perhaps even the 
intrauterine environment. Already the causes of the trait are those determined by genetic traits of behavior.

Preclinical studies, such as the one carried out by Dias (2014), demonstrate transgenerational responses related to learned fear by up to two or more previous generations. We see no reason why this reasoning cannot be used for humans, and if it does apply to humans, learned or acquired fear by our grandparents can result in similar fear responses in subsequent generations; For this reason, we chose the term personality (cause of characteristics determined by the subject's genetics), for defusional anxiety whose nature began in one, two or perhaps even more than three previous generations.

\section{CONCLUSION}

It is a fact that both resentment, in terms of depression or even fear derived from the failure of the psychological resources that sustain it, are the result of a complex system, which, from the point of view of science, encompasses the brain and the structured, formatted circuits and reformatted on the influence of genetics and epigenetics; and that in the Kleinian scope can be understood as José Bleger defined.

Bleger refers to this early system in the mother-child symbolic relationship. A disorganization in this system, whether neuronal or objective in nature, brings out a complex set of depressive and fear symptoms at the same time.

For José Bleger (1977), there is a part that is neither discriminated nor differentiated, which belongs to the subject's self and, in external reality, is called the agglutinated object. According to Bleger, it's a conglomerate with many frustrating and gratifying experiences since the baby's early life.

We understand then that inferring a single nature to the phenomenon of resentment, whether objectual or structural - in biological terms - is, in our view, reductionist. We believe that a more systemic and transdisciplinary view of these psychoanalytic and

RC: 102908

Available in: https://www.nucleodoconhecimento.com.br/psychology/neurosciencesapplied 
biological phenomena greatly increases our ability to intervene in the search for a more adequate waste towards human development based on the being; Whether through the understanding and manipulation of the therapeutic setting and transference and countertransference relationships, or even concomitantly, through careful neuromodulation with psychotropic drugs or transcranial magnetic stimulation (TMS), which will be the object of GEPECH research in the near future (LEFAUCHEUR et al., 2014).

\section{REFERENCES}

ALMEIDA, R. Identificação projetiva, contratransferência e impasse no setting analítico. Revista Mudanças (Universidade Metodista de SP), v. 11, n. 2, p. 213226, 2003.

BATEMAN, A; FONAGY, P. Mentalization based treatment for personality disorders. A practical guide. Oxford, United Kingdom: Oxford University Press, 2016.

BRANDÃO, M. L. et al. Neural organization of different types of fear: Implications for the understanding of anxiety. Revista Brasileira de Psiquiatria, v. 25, n. SUPPL. 2, p. 36-41, 2003.

HOLLIS, J. Os pantanais da Alma: nova vida em lugares sombrios. Toronto. Canadá: Editora Paulus, 1998.

HULLEY, SB; CUMMINGS, SR; BROWNER, WS; GRADY, DG; NEWMAN, T. Delineando a pesquisa clínica: uma abordagem epidemiológica. 3. ed. Porto Alegre: Editora Artimed, 2008.

LEFAUCHEUR, J. P. et al. Evidence-based guidelines on the therapeutic use of repetitive transcranial magnetic stimulation (rTMS). Clinical Neurophysiology, v. 125, n. 11, p. 2150-2206, 2014. 
LIEBERMAN, M. D. Social cognitive neuroscience: A review of core processes. Annual Review of Psychology, v. 58, p. 259-289, 2007.

MELLO, P; MONSON, CA; BERTINI, E; COSTA RRPC; MARTINS, MBA; YAMAMOTO, MN; LEITE, J. Neuropsicanálise e a classificação das posições psicanalíticas neokleinianas. Neurociências e Psicologia, v. 13, p. 21-32, 2017.

MEZZASALMA, M. A.; VALENÇA, A. M.; LOPES, F. L.; NASCIMENTO, I.; ZIN, W. A.; NARDI, A. E. Neuroanatomia do transtorno do pânicoRev Bras Psiquiatr 26 (3), , 2004. Disponível em: <http://dx.doi.org/10.1590/S1516-44462004000300010 >

TRINCA, W. Fobia e pânico em psicanálise. São Paulo. Brasil: Editora Vetor Psico-pedagógica Ltda, 1997.

TURATO, E. R. Métodos qualitativos e quantitativos na área da saúde: definições, diferenças e seus objetos de pesquisa. Revista de Saúde Pública, v. 39, n. 3, p. 507-514, 2005.

YAMADA, M. et al. Induction of galanin after chronic sertraline treatment in mouse ventral dentate gyrus. Brain Research, v. 1516, p. 76-82, 2013.

Submitted: June, 2021.

Approved: November, 2021. 